\title{
Open Legal Policy Peraturan Perundang-undangan Bidang Politik Dalam Putusan Mahkamah Konstitusi (Studi terhadap Putusan MK Bidang Politik Tahun 2015-2017)
}

\author{
Gardha Galang Mantara Sukma \\ Pascasarjana Fakultas Hukum Universitas Islam Indonesia \\ Jln. Cik Di Tiro No. 1, Yogyakarta \\ propagardha@gmail.com
}

\begin{abstract}
This research comprises of two problem formulations: first, why does the Constitutional Court (MK) in six of its decisions asserts that the articles being tested are open legal policies? Second, what are the implications of the open legal policy in terms of the Constitutional Court decisions in the three legislations on politics? This is a juridical normative research with statutory and conceptual approach to regulations. The results of the research are: first, in two of the six decisions of the Constitutional Court, the basis of the consideration of the Constitutional Court is legal norms that are not regulated in details in the 1945 Constitution of the Republic of Indonesia (UUD NRI 1945), it can be deemed as open legal policy. Meanwhile, in the other four decisions of the Constitutional Court, open legal policy was not discussed explicitly but, in conclusion, the basis for asserting the articles reviewed were open legal policy because they were not regulated in details in the 1945 Constitution. Second, the implication of open legal policy of the Constitutional Court decisions in the three legislations on politics are: (1) reduced balance in the state structure, (2) lost opportunities to obtain justice in the social order. Suggestions given are that legislations on politics are easier to be incepted with group interests and pragmatic objectives, hence in examining legislations on politics that have open legal policy, the Constitutional Court must be more careful and courageous because it does not mean that the Constitutional Court cannot review it.
\end{abstract}

Key Words: Constitutional Court decisions; implications; legislations on politics; open legal policy

\begin{abstract}
Abstrak
Penelitian ini memiliki dua rumusan masalah, yaitu: pertama, mengapa Mahkamah Konstitusi (MK) dalam enam putusannya menyatakan bahwa pasal-pasal yang diujikan merupakan open legal policy? Kedua, bagaimanakah implikasi open legal policy ditinjau dari putusan-putusan MK dalam tiga undang-undang bidang politik? Jenis penelitian ini yuridis normatif dengan pendekatan konseptual dan kasus. Hasil penelitian menyimpulkan pertama, dua dari enam putusan MK, dasar dari pentimbangan MK adalah norma hukum yang tidak diatur secara rinci di dalam Undang-Undang Dasar Negara Republik Indonesia Tahun 1945 (UUD NRI 1945) dapat dikatakan open legal policy. Sedangkan, pada empat putusan MK yang lain, tidak secara tersurat open legal policy dibahas tetapi, pada kesimpulannya dasar-dasar untuk mengatakan pasal-pasal yang diujikan termasuk open legal policy karena tidak diatur secara rinci di dalam UUD 1945. Kedua, Implikasi open legal policy dari putusan-putusan MK dalam tiga undang-undang bidang politik yaitu: (1) berkurangnya keseimbangan dalam tatanan kenegaraan, (2) hilangnya kesempatan mendapatkan keadilan dalam tatanan bermasyarakat. Saran yang diberikan yaitu undang-undang dibidang politik yang mengatur tentang berpolitik akan lebih mudah disisipi kepentingan kelompok dan tujuan pragmatis, maka dalam pengujian undang-undang dibidang politik yang bermuatan open legal policy MK harus lebih cermat dan berani karena bukan berarti MK tidak bisa mengujinya.
\end{abstract}

Kata-kata Kunci: Open legal policy, putusan mahkamah konstitusi, peraturan perundang-undangan bidang politik, implikasi 


\section{Pendahuluan}

Pasca reformasi dibentuklah lembaga Mahkamah Konstitusi (MK), keberadaan MK sebagai lembaga negara yang berfungsi menangani perkara tertentu di bidang ketatanegaraan, dalam rangka menjaga konstitusi agar dilaksanakan secara bertanggung jawab sesuai dengan kehendak rakyat dan cita cita demokrasi. Dalam salah satu kewenangannya yaitu pengujian undangundang atau judicial review di dalam politik hukum tidak dapat dilepaskan dari pembicaraan tentang hukum perundang-undangan atau peraturan perundangundangan. Sebab judicial review itu bekerja atas dasar peraturan perundangundangan yang tersusun secara hierarkis. ${ }^{1}$ Keberadaan $\mathrm{MK}$ sekaligus untuk menjaga terselenggaranya pemerintahan negara yang stabil, dan juga merupakan koreksi terhadap pengalaman kehidupan ketatanegaraan di masa lalu yang ditimbulkan tafsir ganda terhadap konstitusi. ${ }^{2}$

Salah satu tugas yang paling mendominasi MK adalah pengujian undangundang terhadap UUD NRI 1945 baik pengujian formal maupun pengujian materiil. Dalam proses pengujian tersebut MK secara sederhana dapat menolak ataupun mengabulkan permohonan dari pemohon. Beberapa kasus dalam putusan MK yang telah diputus dan ditolak di antaranya MK menggunakan dalil open legal policy atau kebijakan hukum terbuka pembentuk undang-undang. Dalam open legal policyatau kebijakan hukum terbuka secara sederhana dapat dimaknai bahwa undang-undang tersebut lahir dari suatu kebijakan pembuat undang-undang dan undang-undang tersebut tidak diatur secara tegas dalam UUD NRI 1945.3 Selama ini dalam beberapa putusannya, MK beberapa kali menggunakan dalil open legal policysebagai landasan untuk memutus dan menolak pengujian undang-undang. Hal ini seolah telah memberikan kebebasan bagi para pembuat undang-undang untuk benar-benar secara bebas membuat materi undang-undang dan kebebasan yang demikianlah yang ditakutkan akan menjadi kesewenang-wenangan.

MK dalam pututusannya di dua tahun terakhir yaitu dari Mei 2017 kebelakang sampai Mei 2015 sudah semakin banyak ditemukan penggunaan kata open legal policydalam beberapa putusan MK, tercatat ada 30 putusan MK yang didalamnya terdapat kata open legal policy. Kata open legal policydapat ditemukan secara tersirat maupun tersurat dalam pertimbangan hukum MK dan di

\footnotetext{
hlm. 131.

1 Ni'matul Huda dan R. Nazriyah, Teori \& Pengujian Peraturan Perundang-undangan, Media, Bandung, 2011,

2 Maruarar Siahaan, Hukum Acara Mabkamah Konstitusi Republik Indonesia, Sinar Grafika, Jakarta, 2012, hlm. 7.

3 http://www.mahkamahkonstitusi.go.id/index.php?page=web.Berita\&id=11867\#.WWUEYIjyg2w, diakses pada tanggal 12 Juli 2017.
} 
antaranya juga dapat ditemukan dalam pendapat pemerintah maupun Dewan Perwakilan Rakyat (DPR). Sebagaimana dijelaskan sebelumnya, dengan menggunakan kata open legal policyMK sering menjadikannya sebagai dalil dalam menolak permohonan pemohon.

Dari ke 30 putusan MK tersebut penulis mencoba membaginya menjadi beberapa bidang dan tercatat ada beberapa bidang yaitu Peradilan, Pajak, Politik dan juga beberapa putusan lainnya yang tidak terspesifikasi lantaran hanya berupa satu putusan saja. Dari beberapa bidang tersebut maka penulis mengambil salah satu bidang untuk dapat diteliti yaitu bidang politik. Di dalam putusan MK yang termasuk ke dalam putusan bidang politik sebenarnya ada 10 putusan, namun demikian penulis hanya akan mengambil 6 putusan, yaitu 2 putusan tentang Undang-Undang Nomor 15 Tahun 2011 tentang Penyelenggara Pemilihan Umum yaitu putusan MK Nomor 102/PUU-XIV/2016 dan No. 101/PUU-XIII/2015, 2 putusan tentang Undang-Undang Nomor 2 Tahun 2011 tentang Perubahan Atas Undang-Undang Nomor 2 Tahun 2008 tentang Partai Politik yaitu putusan MK Nomor 35/PUU-XIV/2016 dan No. 78/PUU-XIII/2015, dan 2 putusan tentang Undang-Undang Nomor 17 Tahun 2014 tentang Majelis Permusyawaratan Rakyat, Dewan Perwakilan Rakyat, Dewan Perwakilan Daerah, dan Dewan Perwakilan Rakyat Daerah (MD3) yaitu putusan MK Nomor 76/PUU-XII/2014 dan No. 79/PUU-XII/2014.

Pada 2 putusan pertama tentang undang-undang Penyelenggaraan Pemilu, pertimbangan open legal policy pada putusan MK Nomor 102/PUU-XIV/2016 berbicara tentang batas usia pencalonan seorang pejabat. Sedangkan pada putusan MK 101/PUU-XIII/2015 berbicara tentang lahirnya lembaga KPU dan Bawaslu serta DKPP sebagai suatu pengaturan lebih lanjut di dalam undangundang.

Pada 2 putusan selanjutnya tentang undang-undang Partai Politik pertimbangan open legal policypada putusan MK Nomor 35/PUU-XIV/2016 berbicara tentang kewenangan pemerintah cq. Menteri Hukum dan HAM untuk menerima permohonan dan melakukan pendaftaran atas penggantian atau perubahan susunan kepengurusan partai politik di tingkat pusat. Sedangkan pada putusan MK Nomor 78/PUU-XIII/2015, berbicara tentang penentuan materi muatan sebuah undang-undang merupakan kewenangan dari lembaga pembentuk undang-undang. Dalam undang-undang partai politik harus dapat menjadi instrumen hukum yang mampu menjamin terwujudnya partai politik yang mandiri, profesional, dan akuntabel yang ditandai dengan kemampuan partai politik menyelesaikan berbagai persoalan yang ada pada dirinya secara 
otonom khususnya permasalahan yang berkaitan dengan sengketa kepengurusan dengan diperkuatnya keberadaan Mahkamah Partai.

Pada 2 putusan terakhir tentang Undang-Undang Majelis Permusyawaratan Rakyat, Dewan Perwakilan Rakyat, Dewan Perwakilan Daerah, dan Dewan Perwakilan Rakyat Daerah pertimbangan open legal policy pada putusan MK 76/PUU-XII/2014 berbicara tentang cara pengisian Pimpinan DPR, mekanisme pemilihan ketua dan wakil ketua DPR. Sedangkan pada Putusan 79/PUUXII/2014 berbicara tentang pengaturan kelembagaan antara DPD dan DPR dimana ada ketimpangan antara pengaturan kelembagaan yang sangat jauh berbeda dari mulai alat kelengkapan hingga hak anggota.

Konsep open legal policy pertama kali dipergunakan oleh MK sekitar tahun 2005, yaitu tepatnya pada 31 Mei 2005 dalam putusannya Nomor 10/PUUIII/2005. ${ }^{4}$ Pada Putusan MK Nomor 10/PUU-III/2005 istilah yang pertama kali dapat dijumpai adalah legal policy, walaupun demikian istilah tersebut tetap merujuk pada pengertian kebijakan. Pada Putusan MK 10/PUU-III/2005 di dalamnya dijelaskan bahwa pengaturan pembatasan threshold adalah sebagai suatu legal policy. Berawal putusan MK 10/PUU-III/2005 ternyata berjalannya waktu penggunaan istilah open legal policy atau legal policy semakin sering didapati di dalam putusan putusan MK.

Dalam bidang hukum sebenarnya konsep open legal policy adalah hal baru dan relatif tidak dikenal sebelumnya, walaupun demikian kita semakin mengenalnya belakangan dari berbagai putusan MK yang sering menggunakan istilah open legal policy dalam putusannya. Dari rentang waktu pertama kali konsep open legal policy dikenalkan dalam putusan MK hingga sampai sekarang sudah sangat banyak putusan-putusan MK yang memperlihatkan istilah open legal policy. Meski demikian, penggunaan konsep open legal policy tersebut nyata-nyata terkadang malah justru menimbulkan masalah baru yang tentunya seperti mengembalikan kepada para pembuat undang-undang atau kebijakan tanpa ada arahan dan batasan yang jelas dari MK, padahal jika dicermati kembali bahwa konsep open legal policy itu juga sangat rawan kewenangan tersebut disalahgunakan. Undang-undang yang lahir dari open legal policy senyatanya sebagai suatu produk hukum oleh manusia tentu terkadang mempunyai kecenderungan disisipi kepentingan pembuatnya atau kepentingan-kepentingan orang atau kelompok tertentu. Jika MK tidak dapat menguji suatu undangundang yang bersifat open legal policy maka kemana undang-undang ini akan diuji hal inilah yang menjadi suatu kelemahan dan cenderung dapat disalah gunakan.

4 Mardian Wibowo, "Menakar Konstitusionalitas sebuah Kebijakan Hukum Terbuka dalamPengujian Undang- Undang”, Jurnal Konstitusi, Vol. 12 No. 2, Juni 2015, hlm. 210. 


\section{Rumusan Masalah}

Berdasarkan uraian di atas maka rumusan masalah dalam tulisan ini adalah sebagai berikut: Pertama, mengapa MK dalam enam putusannya menyatakan bahwa pasal-pasal yang diujikan merupakan open legal policy?; Kedua, bagaimana implikasi open legal policy ditinjau dari putusan-putusan MK dalam tiga undangundang bidang politik tersebut?.

\section{Tujuan Penelitian}

Dalam rencana penelitian ini, penulis bertujuan untuk mendapatkan hasil yakni: Pertama, mengetahui alasan dari MK dalam menyatakan bahwa pasal-pasal yang diujikan merupakan open legal policy; Kedua, menjelaskan implikasi open legal policy dari putusan-putusan MK bidang politik.

\section{Metode Penelitian}

Pendekatan yang dilakukan yakni pendekatan kasus dan konseptual, dimana lebih mengedepankan pengkonsepsian hukum sebagai law in doctrine, meliputi nilai-nilai, norma-norma hukum positif atau pun putusan pengadilan. Dalam penelitian ini, cakupan penelitian yakni seperti penelitian terhadap azasazas hukum, penelitian terhadap sistematika hukum, penelitian terhadap taraf sinkronisasi hukum, yang keseluruhannya ternaung dalam pendekatan konseptual penelitian. ${ }^{5}$

\section{Hasil Penelitian dan Pembahasan}

\section{Open Legal Policy di Putusan-Putusan MK dalam Tiga Undang-Undang Bidang} Politik.

Menurut Mukthie Fadjar, open legal policy atau kebijakan hukum terbuka muncul ketika UUD 1945 memerintahkan untuk mengatur norma tertentu dalam bentuk undang-undang, namun hanya memberikan arahan secara garis besar. Sementara undang-undang yang dibentuk harus mengatur dengan lebih detail. Mengatur dengan lebih detail yang dimaksudkan di sini adalah merupakan wilayah terbuka atau bebas bagi pembentuk undang-undang untuk menentukan selama masih dalam bingkai garis besar yang diatur oleh UUD 1945. Norma undang-undang yang tidak diatur oleh UUD 1945, namun norma tersebut harus ada demi melaksanakan perintah UUD 1945, maka norma yang demikian adalah

${ }^{5}$ Soerjono Soekanto, Pengantar Penelitian Hukum, Cetakan ketiga, UI Press, Jakarta, hlm. 51. 
norma hukum yang masuk kategori kebijakan hukum terbuka atau open legal policy. Norma hukum yang demikian menurut MK boleh diubah oleh pembentuk UU sewaktu-waktu diinginkan. ${ }^{6}$

Melihat dari berbagai putusan-putusan MK yang berkaitan dengan open legal policy maka, dapat ditarik suatu uraian tentang definisi atau arti dari konsepsi open legal policy. Open legal policy menurut MK adalah suatu kondisi ketika terdapat rumusan norma undang-undang yang materi norma dimaksud tidak diatur dalam UUD 1945, atau suatu rumusan norma undang-undang yang muncul sebagai konsekuensi dilaksanakannya perintah eksplisit UUD 1945, sehingga norma undang-undang tersebut tidak dapat dinilai konstitusionalitasnya, serta norma undang-undang tersebut dapat sewaktuwaktu diubah oleh pembentuk undang-undang. Kesimpulan dari konsep MK tentang open legal policy adalah suatu kebebasan bagi pembentuk undang-undang untuk mengatur semua hal yang tidak diperintahkan atau diatur oleh UUD 1945, demi menjamin kelancaran pemerintahan atau aktivitas negara. ${ }^{7}$

Hal menarik yang dapat dilihat dalam perjalanan putusan-putusan MK yang telah diteliti oleh Mardian Wibowo yaitu hingga 2016, belum pernah ada norma open legal policy atau kebijakan hukum terbuka yang dinyatakan oleh MK bertentangan dengan UUD 1945 atau dinyatakan inkonstitusional dan karena hal tersebut tidak memiliki kekuatan hukum mengikat. ${ }^{8}$

Penggunaan istilah open legal policy, pada akhirnya tidak lagi hanya digunakan oleh MK pada putusannya dengan menyebut suatu undang-undang yang diujinya dengan istilah open legal policy. Menurut MK suatu undang-undang yang dinyatakan open legal policy, maka suatu norma yang terkandung di dalam suatu undang-undang atau bahkan undang-undang itu sendiri adalah suatu kebijakan dari pembuat undang-undang. Tetapi istilah open legal policy juga digunakan DPR dan Pemerintah sebagai pembuat undang-undang untuk mempertahankan suatu undang-undang dalam suatu pengujian konstitusional di MK. Tidak hanya digunakan oleh DPR dan Pemerintah, istilah open legal policy juga digunakan para pemohon pengujian hingga juga digunakan para ahli dalam memberikan keterangan-keterangannya baik dalam kapasitasnya sebagai Ahli dari pihak pemohon atau pihak yang berkepentingan mempertahankan suatu undang-undang.

Sudah begitu banyak dan beragamnya penggunaan istilah open legal policy di dalam suatu proses pengajuan pengujian hingga persidangan di MK membuat

${ }^{6}$ Mardian Wibowo, Kebijakan Hukum Terbuka Dalam Putusan Mabkamah Konstitusi konsep dan kajian dalam pembatasan kebebasan pembentuk undang-undang, Rajawali Pers, Jakarta, 2019, hlm. 101-102.

${ }^{7}$ Ibid., hlm. 133-134.

${ }^{8}$ Ibid. 
penulis tergerak untuk meneliti beberapa putusan-putusan yang berkaitan dengan open legal policy terkhusus pada putusan-putusan bidang politik. Putusanputusan MK bidang politik ini penulis temukan setelah menyaring beberapa putusan MK dari Mei 2015 hingga mei 2017. Puluhan putusan MK yang terdapat dalam rentang dua tahun tersebut telah ditemukan sebanyak tiga puluh putusan MK yang bermuatan open legal policy. Selanjutnya, dari tiga puluh putusan MK tersaringlah enam putusan MK yang bermuatan open legal policy dengan kekhususan putusan MK bidang politik.

Muatan open legal policy dalam enam putusan MK bidang politik tersebut, seperti yang telah dijelaskan di atas, telah mengalami suatu perkembangan. Istilah open legal policy tidak lagi hanya digunakan oleh MK dalam menyebut suatu undang-undang yang diujinya sebagai undang-undang yang termasuk open legal policy, tetapi istilah tersebut juga dapat ditemukan dalam alasan permohonan pemohon, keterangan DPR dan pemerintah hingga keterangan ahli baik dari sisi yang mengajukan pengujian hingga sisi yang mempertahankan undang-undang. Berikut ini adalah muatan open legal policy dalam putusan-putusan MK bidang politik yang penulis teliti yaitu Putusan MK Nomor 76/PUU-XII/2014, Putusan MK Nomor 79/PUU-XII/2014, Putusan MK Nomor 78/PUU-XIII/2015, Putusan Nomor MK 101/PUU-XIII/2015, Putusan MK Nomor 35/PUU-XIV/2016, dan Putusan MK Nomor 102/PUU-XIV / 2016.

Pada Putusan MK Nomor 76/PUU-XII/2014 muatan istilah open legal policy digunakan oleh kelompok yang mempertahankan norma hukum dalam undangundang tersebut. Kelompok yang dimaksudkan disini adalah DPR. DPR menyampaikan pendapatnya bahwa konstitusi tidak mengatur cara pengisian pimpinan DPR. ${ }^{9}$

Pada Putusan MK Nomor 79/PUU-XII/2014 muatan istilah open legal policy digunakan oleh kelompok yang mengajukan pengujian dan memberi putusan. Dalam hal ini kelompok yang mengajukan pengujian yang dimaksud di sini adalah keterangan ahli yang disampaikan oleh ahli yaitu Prof. Dr. Yuliandri, S.H., M.H. dengan menyampaikan pendapat bahwa tidak semua materi muatan undang-undang memiliki alat ukur yang jelas, hal tersebut memberikan ruang sebagai open legal policy pembentuk undang-undang dan tentunya membuka kesempatan untuk penyalahgunaan, undang-undang tersebut mesti diwaspadai dan dinilai lebih jauh oleh pengadilan agar tidak lahir dari sebuah maksud yang merugikan rakyat, bangsa dan negara. Pada putusan yang sama ini, pihak yang

${ }_{9}^{9}$ Putusan Mahkamah Konstitusi Nomor 76/PUU-XII/2014, hlm. 69-78. 
memberikan putusan yaitu hakim MK juga terdapat memberikan pendapat yang berbeda dalam putusan. Hakim Arif Hidayat dalam dissenting opinion-nya berpendapat walaupun pemilihan kelengkapan DPR adalah suatu open legal policy. Pemilihan politik hukum yang semacam ini haruslah perlu untuk diuji karena bisa saja undang-undang yang dihasilkan tidak memenuhi syarat pembentukan hukum yang baik sesuai Undang-Undang Nomor 12 Tahun 2011. Pemilihan pimpinan DPR dan kelengkapannya yang selalu berubah-ubah setiap pemilu dapat menimbulkan ketidakpastian hukum. Walaupun ketiadaan peraturan yang rigid dan ekslisit dalam konstitusi melahirkan konsepsi open legal policy tetapi haruslah diingat akan adanya batasan untuk melakukan perubahan itu, yaitu tidak hanya untuk kepentingan yang pragmatis. ${ }^{10}$

Pada Putusan MK Nomor 78/PUU-XIII/2015 muatan istilah open legal policy digunakan oleh kelompok yang mempertahankan norma hukum dalam undangundang tersebut. Dalam hal ini kelompok yang mempertahankan norma hukum dalam suatu undang-undang yang dimaksud di sini adalah pemerintah. Pemerintah memberikan keterangannya bahwa pemerintah menyadari penentuan materi muatan sebuah undang-undang merupakan kewenangan dari lembaga pembentuk undang-undang yang bersifat open legal policy dan pada perinsipnya pemerintah sependapat undang-undang Partai Politik harus dapat menjadi instrumen hukum yang mampu menjamin terwujudnya partai politik yang mandiri, profesional, dan akuntabel dengan salah satu penilainya yaitu dapat secara otonom menyelesaikan sengeketa kepengurusan. ${ }^{11}$

Pada Putusan MK No. 101/PUU-XIII/2015 muatan istilah open legal policy digunakan oleh kelompok yang mengajukan pengujian. Dalam hal ini kelompok yang mengajukan pengujian menggunakan muatan istilah open legal policy untuk memperkuat argumennya dalam mengajukan pengujian yaitu dengan keterangan bahwa pada Pasal 22E ayat (6) telah memberikan suatu mekanisme open legal policy yang melahirkan dua lembaga yakni KPU, Bawaslu dan DKPP dalam Undang-Undang Nomor 15 Tahun 2011 tentang Penyelenggaraan Pemilihan Umum. ${ }^{12}$

Pada Putusan MK Nomor 35/PUU-XIV/2016 muatan istilah open legal policy digunakan oleh kelompok yang mempertahankan norma hukum dalam undangundang, yaitu DPR. DPR memberikan keterangannya bahwa segala ketentuan yang mengatur terkait dengan Partai Politik telah dibuat dalam Undang-Undang Nomor 2 Tahun 2008 sebagaimana telah diubah dengan Undang-Undang Nomor

${ }_{10}^{10}$ utusan Mahkamah Konstitusi Nomor 79/PUU-XII/2014, hlm. 83-203.

${ }_{11}$ Putusan Mahkamah Konstitusi Nomor 78/PUU-XIII/2015, hlm. 61.

12Putusan Mahkamah Konstitusi Nomor 101/PUU-XIII/2015, hlm. 10. 
2 Tahun 2011. Pada undang-undang ini, Pemerintah cq. Menteri Hukum dan HAM diberikan kewenangan untuk menerima dan melakukan pendaftaran atas penggantian atau perubahan susunan kepengurusan partai politik di tingkat pusat dan untuk bukti pendaftaran tersebut dikeluarkan keputusan Menteri Hukum dan HAM. ${ }^{13}$

Pada Putusan MK Nomor 102/PUU-XIV/2016 muatan istilah open legal policy digunakan oleh kelompok yang memberi putusan. Pihak yang dimaksudkan dalam hal ini adalah MK. MK dalam pertimbangan hukumnya memberikan pendapat bahwa sikap dari pembentuk undang-undang mengenai syarat batas usia pencalonan seseorang pejabat adalah suatu kebijakan hukum terbuka, dan hal ini tidak dapat dikategorikan sebagai ketentuan yang tidak konstitusional. UUD 1945 tidak menentukan batas usia minimum tertentu untuk menduduki semua jabatan dan aktivitas pemerintahan. Hal ini merupakan kebijakan hukum terbuka (open legal policy) yang sewaktu-waktu dapat diubah oleh pembentuk undang-undang sesuai dengan tuntunan kebutuhan perkembangan yang apapun pilihannya tidak dapat dianggap bertentangan dengan UUD 1945. ${ }^{14}$

Keenam putusan MK di atas telah memberikan gambaran, bahwa penggunaan istilah open legal policy pada proses pengujian undang-undang di MK yang telah dijelaskan pada putusannya ternyata begitu beragam. Istilah open legal policy tidak lagi hanya menjadi dasar/alasan MK dalam memutus suatu pengujian perundang-undangan, tetapi juga telah digunakan oleh pemohon hingga penyusun undang-undang yaitu DPR dan Pemerintah.

Undang-undang atau norma hukum suatu undang-undang secara sederhana dapat diketahui apakah termasuk yang bersifat open legal policy dengan cara melihat apakah undang-undang tersebut diatur atau termasuk dalam suatu batasan dari norma yang diatur dalam UUD 1945, maka jika undang-undang atau norma di dalam undang-undang tersebut tidak termasuk dalam suatu yang diatur atau diberikan batasan untuk diatur oleh UUD 1945, maka undang-undang atau norma dari undang-undang tersebut dapat dikatakan sebagai open legal policy.

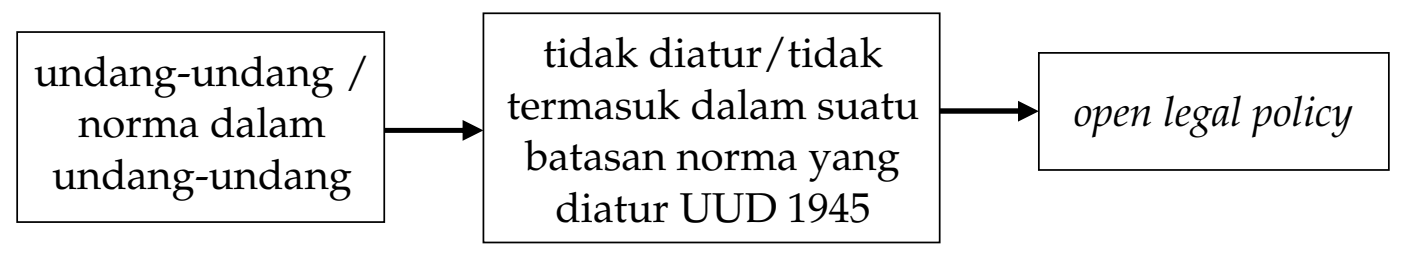

13Putusan Mahkamah Konstitusi Nomor 35/PUU-XIV/2016, hlm. 58.

14Putusan Mahkamah Konstitusi Nomor 102/PUU-XIV/2016, hlm. 22. 
Lebih lanjut Mardian Wibowo juga memberikan syarat suatu norma hukum dinilai sebagai open legal policy yaitu pertama, tidak bertentangan dengan atau tidak mencederai UUD 1945. Kedua, harus memerhatikan tuntunan yang adil sesuai dengan pertimbangan moral, nilai-nilai agama, keamanan, dan ketertiban umum. Ketiga, menjamin hak warga negara. Keempat, logis dan dapat diterima secara hukum. Kelima, memiliki kegunaan. Meski begitu yang perlu diingat bahwa tidak lantas suatu undang-undang atau norma dalam undang-undang yang termasuk open legal policy berhubungan langsung dengan suatu keputusan dalam putusan MK. ${ }^{15}$

Pada Putusan MK Nomor 79/PUU-XII/2014 membahas tentang pengujian Undang-Undang Nomor 17 Tahun 2014 tentang MD3 terhadap UUD 1945 secara singkat pengujian ini melakukan permohonan provisi ${ }^{16}$, pengujian formil, dan pengujian materiil. Pada putusan ini ada perbedaan pandangan antara hakim MK yang satu dengan hakim MK yang lainya. Hakim MK Arif Hidayat memberikan pandangan yang berbeda (dissenting opinion) terkait dengan subtansi pengujian formil dan materiil yang diajukan oleh pemohon. Subtansi pengujian yaitu tentang mekanisme pemilihan pimpinan DPR dan alat kelengkapannya, para pembentuk undang-undang telah bersepakat bahwa mekanisme yang dipilih untuk menentukan pemilihan pimpinan DPR dan alat kelengkapannya adalah dengan cara pemilihan oleh anggota dan tidak lagi berdasarkan pada perolehan kursi terbanyak. Substansi materi tersebut menurut Arif Hidayat merupakan politik hukum terbuka (opened legal policy) pembentuk undang-undang untuk menentukan mekanisme pemilihan pimpinan DPR dan alat kelengkapannya. ${ }^{17}$ Walaupun tidak dijelaskan secara tertulis dasar pertimbangan mengapa hal tersebut dapat dikatakan sebagai open legal policy, namun jika kita mengambil kerangka teori yang sudah penulis sampaikan di atas, maka dapat disimpulkan bahwa "mekanisme pemilihan pimpinan DPR dan alat kelengkapannya" yang tidak diatur secara rinci dalam UUD 1945 membuat hakim MK menyebut norma hukum tersebut sebagai open legal policy.

Pada Putusan MK Nomor 102/PUU-XIV/2016 membahas tentang pengujian Undang-Undang Nomor 15 Tahun 2011 tentang Penyelenggara Pemilihan Umum terhadap UUD 1945 secara singkat pengujian ini melakukan

${ }^{15}$ Mardian Wibowo, Kebijakan Hukum Terbuka. . ., Loc. Cit.

${ }^{16}$ Permohonan provisi merupakan permohonan kepada hakim agar ada tindakan sementara mengenai hal yang tidak termasuk pokok perkara, (dalam hal ini permohonan provisi yang dimaksudkan oleh pemohon yaitu tentang penundaan pemberlakuan Undang-Undang Nomor 17 Tahun 2014 tentang Majelis Permusyawaratan Rakyat, Dewan Perwakilan Rakyat, Dewan Perwakilan Daerah, dan Dewan Perwakilan Rakyat Daerah), lihat https://www.hukumonline.com/klinik/detail/ulasan/lt5110864b5855f/arti-istilah-konvensi--rekonvensi-eksepsi-- an-rovisi/ diakses 13 Juli 2020.

${ }^{17}$ Putusan Mahkamah Konstitusi Nomor 79/PUU-XII/2014, Loc. Cit. 
permohonan pengujian materiil. Substansi dari pengujian ini yaitu berupa batas usia paling rendah untuk dapat mencalonkan anggota, baik dari anggota Komusi Pemilihan Umum Provinsi, Kabupaten atau Kota dan Badan Pengawas Pemilihan Umum Provinsi, Kabupaten atau Kota. MK dalam konsklusinya menyatakan pemohon memiliki kedudukan hukum tetapi pokok permohonan pemohon tidak beralasan hukum. Menurut MK, pengaturan batas usia adalah kewenangan dari pembuat undang-undang (open legal policy) yang berapa pun syarat usia pencalonan ditetapkan tidak dapat dikategorikan sebagai ketentuan yang tidak konstitusional. MK memberi contoh pengaturan batas minimal yang berbeda juga ada di MA dan MK. Usia paling rendah untuk menjadi hakim konstitusi di MK menurut Undang-Undang Nomor 8 Tahun 2011 perubahan atas Undang-Undang Nomor 24 Tahun 2003 adalah 47 tahun. Sedangkan, usia paling rendah untuk menjadi Hakim Agung menurut Undang-Undang Nomor 3 Tahun 2009 tentang Perubahan Kedua atas Undang-Undang Nomor 14 Tahun 1985 adalah 45 tahun. ${ }^{18}$

Empat putusan yang lainnya yaitu Putusan MK Nomor 76/PUU-XII/2014, 78/PUU-XIII/2015, 101/PUU-XIII/2015, dan 35/PUU-XIV/2016. Di dalam keempat putusannya MK tidak menyatakan tersurat maupun tersirat tentang open legal policy dalam materi pengujian ataupun pasal-pasalnya. Meski begitu pernyataan-pernyataan bahwa materi ataupun pasal-pasal yang diujikan adalah open legal policy datang dari pemohon maupun pembuat undang-undang. Pada Putusan MK Nomor 76/PUU-XII/2014 pembuat undang-undang mempunyai dasar-dasar dalam menyatakan materi terkait norma hukum pemilihan ketua DPR dan wakil ketua DPR adalah open legal policy dikarenakan hal tersebut adalah kewenangan pengaturan yang tidak diatur oleh UUD 1945 tepatnya pada Pasal 19 ayat (2) UUD 1945 yang berbunyi "Susunan Dewan Perwakilan Rakyat diatur dengan Undang-undang". ${ }^{19}$

Pada Putusan MK Nomor 78/PUU-XIII/2015 salah satu pembentuk undang-undang yaitu Presiden dalam hal ini diwakilkan oleh pemerintah dengan keterangannya yaitu materi muatan sebuah undang-undang merupakan kewenangan pembentuk undang-undang. ${ }^{20}$ Sedangkan yang dimaksudkan dalam putusan ini adalah tentang Mahkamah Partai Politik. ${ }^{21}$ Mahkamah Partai Politik yang pengaturannya tidak diatur dalam UUD 1945 sudah tentu menjadikannya dasar untuk dikatekorikan termasuk open legal policy.

\footnotetext{
${ }^{18}$ Putusan Mahkamah Konstitusi Nomor 102/PUU-XIV/2016, Loc. Cit.

${ }^{19}$ Putusan Mahkamah Konstitusi Nomor 76/PUU-XII/2014, Loc. Cit

20Putusan Mahkamah Konstitusi Nomor 78/PUU-XIII/2015, Loc. Cit.

${ }^{21}$ Ibid., hlm 84-86.
} 
Pada Putusan MK Nomor 101/PUU-XIII/2015 para pemohon pada materi yang diujikan yaitu tentang proses konsultasi kepada DPR dan Pemerintah yang dilakukan KPU, Bawaslu, dan DKPP terhadap seluruh Peraturan KPU, Peraturan Bawaslu, dan Peraturan DKPP untuk seluruh penyelenggaraan Pemilihan Umum baik pemilihan umum Anggota DPR, DPD, dan DPRD, pemilihan Umum Presiden dan Wakil Presiden, serta Pemilihan Gubernur, Bupati, dan Walikota. Para pemohon menjelaskan bahwa norma hukum tersebut adalah pengaturan lebih lanjut dari amanat Pasal 22E ayat (6) UUD 1945 yang menjadikannya dasar sebagai norma hukum tersebut dikategorikan open legal policy. ${ }^{22}$

Pada Putusan MK Nomor 35/PUU-XIV/2016 salah satu pembentuk undang-undang yaitu DPR memberikan keterangannya terkait dengan materi pengujian yaitu kewenangan Pemerintah cq. Menteri Hukum dan Ham untuk menerima permohonan dan melakukan pendaftaran atas penggantian atau perubahan susunan kepengurusan partai politik di tingkat pusat dan untuk keperluan bukti pendaftaran tersebut dikeluarkan keputusan Menteri Hukum dan HAM. Secara lebih luas DPR memberikan pendapatnya bahwa UndangUndang Partai Politik adalah sebagai sebuah open legal policy dengan berdasarkan perwujudan dari negara hukum untuk mengatur hal-hal yang berkaitan dengan Partai Politik. ${ }^{23}$

\section{Implikasi Open Legal Policy dari Putusan-Putusan MK dalam Tiga Undang- UndangBidang Politik.}

Legal policy atau kebijakan hukum dapat diartikan sebagai tindakan pembentuk undang-undang dalam menentukan subyek, obyek, perbuatan, peristiwa, dan/atau akibat untuk diatur dalam peraturan perundang-undangan. Dengan demikian kata"open" dalam istilah "open legal policy" diartikan sebagai suatu kebebasan bagi pembentuk undang-undang untuk mengambil kebijakan hukum. ${ }^{24}$ Open legal policy sebenarnya adalah suatu jalan dan wadah dari sistem yang menjembatani suatu perkembangan zaman karena tidak semua peraturan mempunyai landasan aturannya dan barang tentu tidak memungkinkan juga untuk UUD 1945 mengatur semua hal sampai hal-hal terkecil.Iwan Satriawan dan Tanto Lailam berpendapat, bahwa persoalan konsepsi open legal policy dalam putusan MK belum memiliki batasan yang jelas menurut konstitusi (UUD 1945), sehingga pengertian positive legislature dan negative legislature ${ }^{25}$ sering dikacaukan

22Putusan Mahkamah Konstitusi Nomor 101/PUU-XIII/2015, Loc. Cit.

23Putusan Mahkamah Konstitusi Nomor 35/PUU-XIV/2016, Loc. Cit.

${ }^{24}$ Iwan Satriawan dan Tanto Lailam, "Open Legal Policy dalam Putusan Mahkamah Konstitusi dan Pembentukan Undang-Undang”, Jurnal Konstitusi, Volume 16, Nomor 3, September, 2019., hlm. 562.

25 Positive legislature artinyaorgan atau lembaga (merujuk pada lembaga negara yaitu DPR dan Pemerintah) yang memiliki kewenangan untuk membuat norma. Sedangkan, negative legislature artinya tindakan 
dalam praktik pembentukan dan pengujian undang-undang. ${ }^{26}$ Keduanya juga berpendapat bahwa open legal policy dalam putusan MK sering menunjukkan adanya kepribadian yang terbelah dalam tubuh MK, antara kubu yang lebih condong menggunakan pendekatan judicial activism dan di sisi lain kubu yang cenderung pada pendekatan judicial restraints. ${ }^{27}$ Judicial activism sendiri merupakan respon dan adaptasi pengadilan terhadap perubahan sosial dengan cara mengembangkan prinsip-prinsip yang diambil dari teks konstitusi dan putusan yang telah ada guna mengimplementasikan nilai-nilai dasar dari konstitusi secara progresif. ${ }^{28}$ Langkah tersebut untuk menghindari kekosongan hukum yang terlalu lama karena menunggu proses pembentukan hukum di lembaga legislatif. Sedangkan pada prinsip judicial restraint berbanding terbalik, prinsip ini mengekang pengadilan untuk bertindak selayaknya sebuah "miniparliament"29

Iwan Satriawan dan Tanto Lailam juga menyebutkan bahwa beberapa putusan MK yang mengandung open legal policy sering salah kaprah dan tidak berdasar pada basis konstitusi yang kuat, pendapat ini didasarkan dari berbagai putusan MK yang argumentasi open legal policy-nya justru berpihak pada judicial restraints, tetapi dalam putusan yang lain justru lebih mengutamakan judicial activism. Artinya, ada ketidakjelasan tolok ukur MK dalam menerapkan apakah mereka menggunakan pendekatan judicial activism dan judicial restraints terkait argumentasi open legal policy. ${ }^{30}$ Contohnya pendekatan judicial activism yang dimaksud adalah dengan adanya pendapat yang berbeda oleh hakim Arif Hidayat tentang Zina dalam Putusan MK Nomor 46/PUU-XIV/2016. Hal serupa juga terjadi pada salah satu putusan dari beberapa putusan yang penulis teliti yaitu pada Putusan MK Nomor 79/PUU-XII/2014, hakim Arif Hidayat memiliki pendapat yang berbeda tentang norma hukum terkait mekanisme pemilihan pimpinan DPR dan kelengkapanya dimana aturannya yang berubah-ubah hingga mengakibatkan ketidakpastian hukum.

MK yang membatalkan norma yang ada dalam suatu undang-undang bila bertentangan dengan UUD 1945. lihat https://www.hukumonline.com/klinik/detail/ulasan/lt5c062fbc83162/mahkamah-konstitusi-seba gaiinegativelegis lator-i-dan-ipositive-legislator-i diakses 30 Juni 2020.

${ }^{26}$ Iwan Satriawan dan Tanto Lailam, Open Legal Policy Dalam ..., Loc. Cit.

${ }^{27}$ Ibid., hlm. 570.

${ }^{28}$ Pan Muhammad Faiz Kusuma Wijaya, Dimensi Judicial Activism dalam Putusan Mabkamab Konstitusi,Jurnal

Konstitusi, Volume 13, Nomor 2, Juni 2016, hlm. 409. dikutip kembali Iwan Satriawan dan Tanto Lailam, Open Legal Policy..., Ibid.

29 Philip A. Talmadge, Understanding the Limits of Power: Judicial Restraint in General Jurisdiction Court Systems, Seattle University Law Review, Volume 22 Nomor 695, 1999, hlm. 711 dikutip kembali Iwan Satriawan dan Tanto Lailam, Open Legal Policy. .., Ibid.

${ }^{30}$ Ibid., hlm 572 . 
Pembentuk undang-undang yang memiliki keleluasaan merumuskan norma hukum sejatinya tidak lantas membuatnya dapat dengan sesuka hati dalam membuatnya, ibarat suatu kertas kosong, pembentuk undang-undang tidak bisa menulis apa saja sesuai dengan keinginannya. Menurut Radita Ajie, pembentuk undang-undang haruslah mempunyai dasar, motif, tujuan atau terdapat kebutuhan konstitusional untuk menentukan pilihan-pilihan itu. Menurutnya hal yang demikian disebut dengan konsep akuntabilitas konstitusi bagi para pembentuk undang undang di hadapan konstitusi. Jika ternyata tidak ada kebutuhan konstitusional atau ternyata dasar, motif, atau tujuan hukum dibalik pilihan model tersebut ternyata tidak terbukti, atau kebutuhan konstitusional ketika pilihan itu dibuat pada masa tertentu ternyata sudah tak dibutuhkan lagi maka tentunya pilihan tersebut menurutnya sesungguhnya bisa menjadi inkonstitusional pada masa depan. ${ }^{31}$

Praktek penerapan open legal policy dalam pengujian perundang-undangan di MK yang sudah terjadi lebih dari satu dekade dari mulai pertama kali istilah ini dikenalkan oleh MK pada putusannya di 2005 ternyata belum menghasilkan suatu putusan yang membatalkan norma open legal policy. MK seolah berlindung dari istilah open legal policy untuk tidak menguji suatu norma yang dibuat berdasarkan kebijakan terbuka dari pembuat undang-undang, rasanya MK seperti mencari rasa aman. Jika menelisik lebih jauh ternyata politik hukum lahirnya konsep "open legal policy" di berbagai negara merupakan bentuk dari sikap menahan diri (judicial restraint) MK. Sikap menahan diri MK tersebut guna memberi ruang gerak kepada pembentuk undang-undang. Sikap tersebut merupakan upaya untuk mengurangi ketegangan politik antar lembaga negara. ${ }^{32}$ Langkah MK yang diambil di Indonesia tentu memiliki Implikasi, praktek yang membiarkan pembentuk undang-undang seolah dapat dengan bebas merumuskan norma hukum dengan dalih itu sebagai open legal policy dan tidak dapat di uji oleh MK. MK sendiri menurut penulis sudah mengalami kemajuan sedikit demi sedikit dalam menilai open legal policy dalam pengujiannya. Hakim MK seperti Arif Hidayat telah membuka suara dalam dissenting opinion di Putusan MK Nomor 79/PUU-XII/2014 terkait pengujian terhadap suatu norma hukum dalam undang-undang yang bersifat open legal policy, mereka berfokus

${ }^{31}$ Radita Ajie, "Batasan Pilihan Pembentuk Undang-Undang (Open Legal Policy) dalam Pembentukan Peraturan Perundang-undangan Berdasarkan Tafsir Putusan Mahkamah Konstitusi (Limit To Open Legal Policy In Legislation Making Based On Constitusional Court Decision)", Jurnal Legislasi Indonesia, Vol. 13 No. 02, Juni, 2016, hlm. 112.

32 Bisyariyadi, Yudisialisasi Politik dan Sikap Menahan Diri: Peran Mahkamah Konstitusi dalam Menguji Undang- Undang, Jurnal Konstitusi, Volume 12, Nomor 3, September 2015, hlm. 489. dikutip kembali oleh Muhammad Addi Fauzani dan Fandi Nur Rohman, Urgensi Rekonstruksi Mahkamah Konstitusi dalam Memberikan Pertimbangan Kebijakan Hukum Terbuka (Open Legal Policy), Jurnal Hukum, Volume 35, Nomor 2, Desember, 2019., hlm. 142. 
pada (pengujian formal) bagaimana suatu undang-undang apakah sudah sesuai dalam pembentukannya, sehingga aturan yang terbentuk dapat memberikan kepastian hukum.

Open legal policy yang terus dibiarkan begitu saja dengan tanpa batasan dan kemungkinan untuk diuji menurut penulis setidaknya akan menimbulkan dua implikasi dalam tatanan ketatanegaraan dan tatanan keadilan masyarakat. Pertama, dari segi tatanan ketatanegaraan, lahirnya lembaga MK adalah suatu buah dari reformasi. MK merupakan sebuah kebutuhan mendasar dari upaya perjuangan reformasi yang mencita-citakan terwujudnya negara demokrasi konstitusial. ${ }^{33}$ Salah satu kewenangan MK yang diamanatkan oleh UUD 1945 yaitu mengadili pada tingkat pertama dan terakhir yang putusannya bersifat final untuk menguji undang-undang terhadap undang-undang dasar. ${ }^{34}$ Kewenangan menguji undang-undang atau Judicial Review bisa juga dikatakan sebagai pengawasan kekuasaan kehakiman (Judicial Power) terhadap kekuasaan Legislatif dan Eksekutif. Menurut BrewerCarrias hal tersebut sebagai tugas yang melekat dari pengadilan untuk menjamin tindakan hukum Legislatif dan Eksekutif sesuai dengan hukum tertinggi, dikatakan: "...the same inherent duty of courts to ensure that each legal action conforms to a superior law" ${ }^{35}$ Sejauh ini tidak diujinya suatu undang-undang ataupun norma hukum dalam undang-undang yang termasuk dalam open legal policy, hanya akan memberikan ketidak seimbangan tatanan kenegaraan di Indonesia. Praktek kebiasaan menggunakan dan berlindung dari istilah open legal policy dalam penelitian ini sejatinya sudah tidak lagi hanya digunakan oleh MK saja seperti pada Putusan MK Nomor 102/PUU-XIV/2016 tetapi juga mulai sering digunakan oleh pembentuk undang-undang yaitu pada Putusan MK Nomor 35/PUU-XIV/2016 dan 76/PUU-XII/2014. Praktek yang demikian ditakutkan hanya akan membuat pembentuk undang-undang sewenang-wenang dalam membentuk undang-undang atau norma hukum dalam suatu undang-undang.

Kedua, dari segi tatanan keadilan masyarakat. undang-undang sebagai produk hukum erat juga dikatakan sebagai produk politik, dari keduanya kita dapat mengenal suatu politik hukum dari pembentukan undang-undang. Ada beberapa hal yang perlu diingat dari pendapat Moh. Mahfud MD berkaitan tentang studi politik hukum. Pertama, arah resmi tentang hukum yang akan

${ }^{33}$ Soimin dan Mashuriyanto, Mabkamah Konstitusi dalam Sistem Ketatanegaraan Indonesia, UII Press, Yogyakarta, 2013, hlm. 134-135.

${ }^{34}$ Lihat Undang Undang Dasar 1945 Pasal 7B dan 24C.

${ }^{35}$ Ni'matul Huda, Negara Hukum, Demokrasi dan Judicial Review, UII Press, Yogyakarta, 2005, hlm. 74. 
diberlakukan atau tidak diberlakukan (legal policy) hal ini diperuntukan guna mencapai tujuan negara yang mencakup penggantian hukum lama dan pembentukan hukum-hukum yang baru sama sekali. Kedua, latar belakang politik dan subsistem kemasyarakatan lainnya dibalik lahirnya hukum. ${ }^{36}$ Hukum sebagai produk politik berkaitan erat dengan politik yang melahirkan suatu hukum, bagaimana karakter suatu hukum tersebut tidak lain adalah hasil dari politik yang melahirkannya. Lembaga pembuat hukum atau lembaga legislatif adalah merupakan tempat pertarungan politik untuk mengkristalkan gagasan-gagasan tentang hukum oleh sebab itu lembaga legislatif lebih dekat dengan politik daripada dengan hukum. ${ }^{37}$ Suatu norma hukum yang open legal policy juga tidak dapat dipisahkan dari proses politik yang melatarbelakanginya, hal ini tentu akan penuh dengan kepentingan dari pembentuk undang-undang. Contoh nyata yang dapat dilihat dalam penelitian ini ada pada putusan MK Nomor 79/PUUXII/2014, open legal policy dari ketentuan pemilihan pimpinan DPR dan kelengkapannya yang selalu berubah-ubah tiap pemilu. Hal ini tentu akan membuat ketidakpastian hukum, sehingga hanya akan merugikan rakyat, terlebih masyarakat pengguna hak pilih yang berharap pimpinan DPR dan kelengkapannya berasal dari partai yang memperoleh suara terbanyak yang tentu juga mewakili dari sebagian besar kepercayaan masyarakat.

\section{Penutup}

Berdasarkan uraian analisis di atas, maka dapat ditarik kesimpulan sebagai berikut. Pertama, pada enam putusan MK dari undang-undang bidang politik di atas, dua diantaranya yaitu Putusan MK Nomor 79/PUU-XII/2014 dan 102/PUU-XIV/2016, MK pada pertimbangan menyebutkan materi yang diujikan adalah open legal policy dari keduanya dapat disimpulkan dasar dari pentimbangan MK adalah norma hukum yang tidak diatur secara rinci di dalam UUD 1945 dapat dikatakan open legal policy. Sedangkan, pada keempat putusan MK yang lain yaitu Putusan MK Nomor 76/PUU-XII/2014, Nomor 78/PUUXIII/2015, Nomor 101/PUU-XIII/2015, dan Nomor 35/PUU-XIV/2016. MK tidak secara tersurat membahas open legal policy tetapi hal ini justru datang dari pemohon, keterangan ahli hingga pembentuk undang-undang baik DPR maupun

${ }^{36}$ Lawrence M. Friedman, A History of American law, Simon dan Schuster, New York, 1973;juga dalam Lawrence M. Friedman, American Law: an Introduction, W.W. Norton and Company, New York, 1984 yang dikutipkembali olehMoh. Mahfud MD, Membangun Politik. Hukum Meneggakkan Konstitusi, Pustaka LP3ES, Jakarta, hlm. 5 .

${ }^{37}$ Satjipto Rahardjo, Beberapa Pemikiran Tentang Ancangan Antara Disiplin Dalam Pembinaan Hukum Nasional, Sinar Baru, Bandung, 1985, Hal. 79. yang dikutip kembali oleh Moh. Mahfud MD, Karakter Produk. Hukum Zaman Kolonial studi tentang politik dan karakter produk hukum pada zaman penjajahan di indonesia, UII Press, Yogyakarta, 1999, hlm. 7. 
Pemerintah yang pada kesimpulannya dasar-dasar mengatakan pasalpasal/norma hukum/materi yang diujikan termasuk open legal policy adalah karena hal tersebut tidak diatur secara rinci di dalam UUD 1945. Telah dapat disimpulkan juga Indikator muatan istilah open legal policy dalam beberapa putusan MK bidang politik di atas dapat di telaah setidaknya menjadi beberapa hal: (a) muatan open legal policy dari pemohon, (b) muatan istilah open legal policy dari pembentuk, dan (c) muatan istilah open legal policy dari yang menguji. Berdasarkan ketiga aspek tersebut teridentifikasi istilah dan konsep open legal policy tidak hanya digunakan oleh MK dalam memberikan putusan pengujian undang-undang tetapi juga digunakan oleh pembentuk undang-undang untuk mempertahankan norma hukum open legal policy dan dalam perkembangannya juga digunakan oleh pemohon saat pengujian undang-undang.

Kedua, implikasi open legal policy dari putusan-putusan MK dalam tiga undang-undang bidang politik yaitu (1) berkurangnya keseimbangan dalam tatanan kenegaraan, (2) hilangnya kesempatan mendapatkan keadilan dalam tatanan bermasyarakat. Istilah dan konsep open legal policy yang tidak dapat di uji oleh MK hanya akan menimbulkan superioritas lembaga pembentuk undangundang sehingga mengabaikan prinsip checks and balances, sedangkan masyarakat hanya akan menjadi korban ketidakpastian hukum dari undang-undang yang syarat akan kepentingan pembentuk undang-undang.

Berdasarkan kesimpulan di atas, penulis menyampaikan beberapa saran sebagai berikut: pertama, kedepannya MK harus lebih berani untuk melakukan pengujian demi mewujudkan rasa adil untuk masyarakat, alih-alih hanya untuk mencari aman. Kedua, undang-undang sebagai produk politik akan dekat dengan kepentingan politik, sedangkan undang-undang dibidang politik yang mengatur tentang berpolitik akan lebih mudah disisipi kepentingan kelompok dan tujuan pragmatis, maka dalam pengujian undang-undang dibidang politik yang bermuatan open legal policy MKharus lebih cermat. Ketiga, pada pengujian undangundang yang termasuk open legal policy, MK harus menggali lebih dalamtujuan dari dibuatnya norma hukum atau undang-undangoleh pembentuk undangundang, terlebih lagi dalam undang-undang bidang politik yang sarat akan kepentingan kelompok dan kepentingan sesaat atau pragmatis. Keempat, pada pengujian undang-undang yang termasuk open legal policy terkhusus bidang politik, para pemohon hendaknya mempertimbangkan untuk juga melakukan permohonan pengujian terkait dengan kepatuhan dalam pembentukan undangundang. Kelima, kedepannya penting kiranya untuk MK dapat menguji dan 
memutus undang-undang atau suatu norma undang-undang yang termasuk open legal policy agar tercipta keseimbangan antar lembaga.

\section{Daftar Pustaka}

\section{Buku}

Huda, Ni'matul, Negara Hukum, Demokrasi dan Judicial Review, UII Press, Yogyakarta, 2005.

dan Nazriyah, R, Teori \& Pengujian Peraturan Perundang-undangan, Media, Bandung, 2011.

Mahfud MD, Moh., Membangun Politik Hukum Meneggakkan Konstitusi, Pustaka LP3ES, Jakarta.

Mahfud MD, Moh., Karakter Produk Hukum Zaman Kolonial studi tentang politik dan karakter produk hukum pada zaman penjajahan di indonesia, UII Press, Yogyakarta, 1999.

Mardian Wibowo, Kebijakan Hukum Terbuka Dalam Putusan Mahkamah Konstitusi konsep dan kajian dalam pembatasan kebebasan pembentuk undang-undang, Rajawali Pers, Jakarta, 2019

Soekanto, Soerjono, Pengantar Penelitian Hukum, Cetakan ketiga, UI Press, Jakarta.

Siahaan, Maruarar, Hukum Acara Mahkamah Konstitusi Republik Indonesia, Sinar Grafika, Jakarta, 2012.

Soimin dan Mashuriyanto, Mahkamah Konstitusi dalam Sistem Ketatanegaraan Indonesia, UII Press, Yogyakarta, 2013.

Wibowo, Mardian, Kebijakan Hukum Terbuka Dalam Putusan Mahkamah Konstitusi konsep dan kajian dalam pembatasan kebebasan pembentuk undang-undang, Rajawali Pers, Jakarta, 2019.

\section{Jurnal}

Iwan Satriawan dan Tanto Lailam, “Open Legal Policy dalam Putusan Mahkamah Konstitusi dan Pembentukan Undang-Undang", Jurnal Konstitusi, Volume 16, Nomor 3, September, 2019.

Mardian Wibowo, "Menakar Konstitusionalitas sebuah Kebijakan Hukum Terbuka dalamPengujian Undang-Undang", Jurnal Konstitusi, Vol. 12 No. 2, Juni 2015.

Muhammad Addi Fauzani dan Fandi Nur Rohman, Urgensi Rekonstruksi Mahkamah Konstitusi dalam Memberikan Pertimbangan Kebijakan Hukum Terbuka (Open Legal Policy), Jurnal Hukum, Volume 35, Nomor 2, Desember, 2019.

Radita Ajie, "Batasan Pilihan Pembentuk Undang-Undang (Open Legal Policy) dalam Pembentukan Peraturan Perundang-undangan Berdasarkan Tafsir Putusan Mahkamah Konstitusi (Limit To Open Legal Policy In Legislation Making Based On Constitusional Court Decision)", Jurnal Legislasi Indonesia, Vol. 13 No. 02, Juni, 2016. 


\section{Internet}

"Konsep Open Legal Policy Perlu Dikoreksi", http:/ /www.mahkamahkonstitusi. go.id/index.php?page=web.Berita\&id=11867\#.WWUEYIjyg2w, diakses pada tanggal 12 Juli 2017.

"Arti istilah konvensi rekonvensi dan provisi" https:/ /www.hukumonline.com/ klinik/detail/ulasan/lt5110864b5855f/arti-istilah-konvensi--rekonvensi-eksepsi--an-rovisi/ diakses 13 Juli 2020.

\section{Peraturan Perundang-Undangan}

Undang Undang Dasar 1945

\section{Putusan Pengadilan}

Putusan Mahkamah Konstitusi Nomor 76/PUU-XII/2014.

Putusan Mahkamah Konstitusi Nomor 79/PUU-XII/2014.

Putusan Mahkamah Konstitusi Nomor 78/PUU-XIII/2015.

Putusan Mahkamah Konstitusi Nomor 101/PUU-XIII/2015.

Putusan Mahkamah Konstitusi Nomor 35/PUU-XIV / 2016.

Putusan Mahkamah Konstitusi Nomor 102/PUU-XIV/2016. 